Journal of Engineering Sciences, Assiut University, Vol. 40, No. 5, pp.1389-1397 - September 2012.

\title{
DESIGN AND SIMULATION OF A GRID-CONNECTED PHOTOVOLTAIC SYSTEM FOR THE EE DEPARTMENT BUILDING IN ASSIUT UNIVERSITY
}

\author{
Ahmed G. Abo-Khalil \\ Electrical Engineering Department, Assiut University, Egypt \\ E-mail:a_galal@aun.edu.eg
}

(Received September 26, 2011 Accepted June 27, 2012)

This paper presents the complete design of a grid-connected Photovoltaic (PV) system to supply electric power for the Department of Electrical Engineering in Assiut University, Assiut Province, Egypt according to their energy requirements. This system can be installed on the roof and the south side of the Department of Electrical Engineering. Homer software is used as the sizing and optimization tool to determine the size and specifications of photovoltaic system components, system cost and estimation of corresponding produced electrical power. Simulation results and analyses are presented to validate the proposed system configuration.

Keywords: PV system, Homer software, PV sizing.

\section{INTRODUCTION}

Over the last two decades, there have been two major events that led the world's industrialized nations to look at renewable energy sources as a supplement to providing the projected increase in energy demand in their respective nations. These events include the world's energy crisis of the mid 1970s and the increased awareness of the effects of emissions from fossil fueled power plants to both humans and the environment. In order to ameliorate the potential harm from these emissions, governments in industrialized countries are currently debating and enacting pollution control regulations into laws. These laws are geared towards both small and large emission sources [1], [2].

Among a wide range of renewable energy projects in progress throughout the world, photovoltaic (PV) systems are the most promising as a future energy technology. The overall objective of photovoltaic technology is to obtain electricity from the sun that is cost competitive and even advantageous with respect to other energy sources. Photovoltaic generation is already a reality in some environments, but of their diffusion in rural areas, there still exists many constraints and the problem needs to be examined from the economic, technical, operational and institutional viewpoints [3].

Photovoltaic (PV) energy generating systems (or PV systems) convert the sun's energy directly into electricity using state-of-the-art semiconductor materials. PV systems vary in complexity. Some are called a "stand-alone or off-grid" system, which means they are the sole source of power to a home, water pump or other loads. Standalone systems can be designed to run with or without backup battery. Remote water 
pumps are often designed to run without battery backup, since water pumped out of the ground during daylight hours can be stored in a holding tank for use any time. In contrast, stand-alone home power systems often store energy generated during the day in a battery bank for use at night. Stand-alone systems are often cost-effective when compared to alternatives such as utility line extensions.

Other PV systems are called "grid-connected" systems. These work to supplement existing electric service from a utility company. When the amount of energy generated by a grid-connected PV system exceeds the customer's loads, excess energy is exported to the utility, turning the customer's electric meter backward. Conversely, the customer can draw needed power from the utility when energy from the PV system is insufficient to power the building's loads. Under this arrangement, the customer's monthly electric utility bill reflects only the net amount of energy received from the electric utility. Each type of system requires specific components besides the PV modules. Generating AC power requires a device called an inverter. The final cost of any PV system ultimately depends on the PV array size and on the other components required for the specific application [4].

This paper provides a design of grid-connected PV system for Department of Electrical Engineering in Assiut University including suggested load profiles, sizing of a PV system for supplying the electrical load of the faculty using Hybrid Optimization Model for Electric Renewable (Homer) software. Homer contains a number of energy component models and evaluates suitable technology options based on cost and availability of resource. Analysis with Homer requires information on economic constraints and control methods. It also requires input on component types, their numbers, costs, efficiency, lifetime, etc. Sensitivity analysis could be done with variables having a range of values instead of a specific number. This allows one to ascertain the effects of change in a certain parameter on the over all system [4].

\section{PV SYSTEM SIZING}

The Electrical Engineering Department is about $1200-\mathrm{m}^{2}$ building located on the south side of Assiut University, Assiut. The department is used by the undergraduate and graduate students all over the year. One of the department research group's missions is to study the performance and feasibility of using the renewable energy sources in the surrounding community. This research aims to design a photovoltaic system that provides the required electrical power to the different laboratories, halls, seminar rooms, classes, offices and library. The department consists of two buildings that serve over 1000 students, 100 faculty members, and 50 employees and technicians each year. The electrical loads of the department consists of air-conditions, lamps, fans, computers and other loads. The total load demand of department is about 300 $\mathrm{KW}$ as shown in table 1 . However, these loads do not work all at one time on the contrary, working for a short time.

The sizing procedure is as follows [5]:

\section{A. Radiation Data}

The amount of useful sunshine available for the panels on an average day during the worst month of the year is called the "insolation value". The worst month is used for analysis to ensure the system will operate year-round. In Assiut, average solar 
insolation is 6.0 hours per day in December. The insolation value also can be interpreted as the kilowatt-hours per day of sunlight energy that fall on each square meter of solar panels at latitude tilt.

Table 2 shows the monthly average values of global solar radiation over Assiut [6]. It is clear from the table that solar energy incident on the region is very high especially during summer months with average daily radiation during June $8.01 \mathrm{KWh} / \mathrm{m} 2 /$ day.

Table 1: Typical electrical appliances used in the Electrical Engineering Department

\begin{tabular}{|c|c|c|c|c|}
\hline Floor & $\begin{array}{c}\text { Lights } \\
\mathbf{4 0 ~ W}\end{array}$ & $\begin{array}{c}\text { Fans } \\
\mathbf{8 0 ~ W}\end{array}$ & $\begin{array}{c}\text { Air- } \\
\text { conditions } \\
\text { 3 HP }\end{array}$ & Other loads \\
\hline Ground \& first & 755 & 51 & 74 & - \\
\hline second & 488 & 0 & 17 & - \\
\hline third & 343 & 21 & 7 & - \\
\hline fourth & 354 & 16 & 5 & - \\
\hline Sum & 1940 & 88 & 103 & - \\
\hline Total power & $77600 \mathrm{~W}$ & $3520 \mathrm{~W}$ & $230514 \mathrm{~W}$ & $30000 \mathrm{~W}$ \\
\hline
\end{tabular}

Table 2: The monthly average values of daily global solar radiation (Kwh/m/day) in Assiut City

\begin{tabular}{|c|c|}
\hline Month & $\begin{array}{c}\text { Daily Radiation in } \\
\text { Kwh/m2/day }\end{array}$ \\
\hline January & 3.18 \\
\hline February & 4.30 \\
\hline March & 5.60 \\
\hline April & 6.68 \\
\hline May & 7.39 \\
\hline June & 8.01 \\
\hline July & 7.93 \\
\hline August & 7.36 \\
\hline September & 6.34 \\
\hline October & 4.93 \\
\hline November & 3.73 \\
\hline December & 2.96 \\
\hline
\end{tabular}

\section{B. Load Data}

The preferred method for determining PV system loads is a "bottom-up" approach in which every daily load is anticipated and summed to yield an average daily total. For PV systems designed to power simple loads, such as a single fan, electric light or other appliance, this method is easy. Simply look at the nameplate power rating on the appliance to calculate its power consumption in watt. 
Finally all the different loads in the building need to be estimated on a typical day and sum them. Table 3 provides the calculations of the power and energy of the electrical engineering department. The daily load profiles were determined by calculating the power demand (Kwh/day) for all load types in the department during the four seasons. The estimated daily energy consumption is given in Table 3. It is shown that, autumn has the highest energy consumption (129.600 KWh /day) compared to the other seasons. However, loads seem very close in the autumn and winter and spring. The average annual load energy is about $100 \mathrm{KWh} / \mathrm{day}$.

\section{PV Array Size and Cost}

For a PV system powering loads that will be used every day, the size of the array is determined by the daily energy requirement divided by the sun-hours per day. For systems designed for non-continuous use (such as schools, governmental offices, etc.), multiply the result by the days per week the loads will be active divided by the total number of days in the week. In our case, for the university buildings, multiply by $6 / 7$. Generally, grid-connected systems are designed to provide from 10 to $60 \%$ of the energy needs with the difference being supplied by utility power. In this paper we take the ratio of $25 \%$ of the needed energy to be covered by the PVs. So, the total power of the PV system is $75 \mathrm{KW}$.

Many PV modules can be purchased at retail for about \$2 per watt for most medium systems in the 75,000 watt range. Of course, there are opportunities to purchase modules for a lower price, especially when your system is larger and you can buy in bulk. An inverter will be needed for systems that output AC power. For stand-alone systems the inverter should be sized to provide $125 \%$ of the maximum loads you wish to run simultaneously at any one moment. Inverters designed for residences and other small systems can be purchased at retail for about $\$ 1$ per rated watt.

Table 3: The daily load energy consumption

\begin{tabular}{|c|c|c|c|c|c|c|c|c|c|c|}
\hline \multirow{2}{*}{$\begin{array}{c}\text { Load } \\
\text { type }\end{array}$} & $\begin{array}{c}\text { No. } \\
\text { Of } \\
\text { units }\end{array}$ & $\begin{array}{c}\text { Rated } \\
\text { power } \\
\text { (W) }\end{array}$ & $\begin{array}{c}\text { Av.hrs } \\
\text { used/ } \\
\text { day }\end{array}$ & $\begin{array}{c}\text { KWh } \\
\text { / day }\end{array}$ & $\begin{array}{c}\text { Av.hrs } \\
\text { used/ } \\
\text { day }\end{array}$ & $\begin{array}{c}\text { KWh } \\
\text { / day }\end{array}$ & $\begin{array}{c}\text { Av.hrs } \\
\text { used/ } \\
\text { day }\end{array}$ & $\begin{array}{c}\text { KWh } \\
\text { / day }\end{array}$ & $\begin{array}{c}\text { Av.hrs } \\
\text { used/ } \\
\text { day }\end{array}$ & $\begin{array}{c}\text { KWh } \\
\text { / day }\end{array}$ \\
\hline Lights & 1940 & 40 & 2 & 15.520 & 2 & 15.520 & 1 & 7.760 & 1 & 7.760 \\
\hline Fans & 88 & 80 & 2 & 14.080 & - & - & 2 & 14.080 & 2 & 14.080 \\
\hline Computers & 100 & 200 & 4 & 80.000 & 4 & 80.000 & 4 & 80.000 & 1 & 20.000 \\
\hline Other loads & - & - & - & 20.000 & - & 20.000 & - & 20.000 & - & - \\
\hline $\begin{array}{c}\text { Total KWh } \\
\text { / day }\end{array}$ & & & & 129.600 & & 115.520 & & 121.840 & & 41.840 \\
\hline
\end{tabular}

\section{Homer Analysis}

Figure 1 shows the proposed scheme as implemented in the Homer simulation tool. A grid-connected PV system consists of a primary energy source, power inverter to maintain the flow of energy between the AC and DC sides and the grid-utility. Figure 2 shows the optimization result for the given solar radiation in Assiut, load data, economics and constraints, Homer simulates one optimal configuration from the given search space. This configuration is a grid-connected PV system that supplies the electrical energy to the load with the lowest net present cost. 


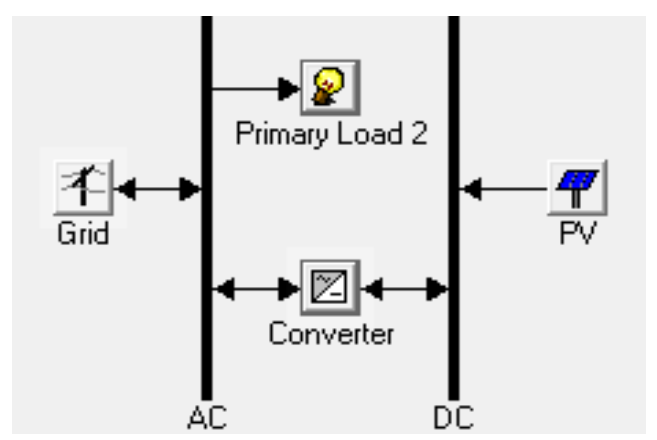

Fig.1: Homer implementation of the stand-alone PV System

\begin{tabular}{|c|c|c|c|c|c|c|c|}
\hline 19 & $\begin{array}{c}\text { PV } \\
(\mathrm{kW})\end{array}$ & $\begin{array}{l}\text { Conv. } \\
(\mathrm{kW})\end{array}$ & $\begin{array}{l}\text { Grid } \\
(\mathrm{kW})\end{array}$ & $\begin{array}{c}\text { Initial } \\
\text { Capital }\end{array}$ & $\begin{array}{c}\text { Operating } \\
\text { Cost (\$/yr) }\end{array}$ & $\begin{array}{l}\text { Total } \\
\text { NPC }\end{array}$ & $\begin{array}{c}\mathrm{COE} \\
(\mathrm{S} / \mathrm{kWh})\end{array}$ \\
\hline 甲 & 75 & 75 & 1000 & $\$ 10.0$ & 9,225 & \$ 140 . & 0.109 \\
\hline
\end{tabular}

Fig.2: The optimization result of homer

\section{SOLAR ARRAY CHARACTERISTICS}

Solar cells are devices that convert photons into electrical potential in a PN junction, of which equivalent circuit is shown in Fig. 3. Due to the complex physical phenomena inside the solar cell, manufacturers usually present a family of operating curves (V-I) as shown in Fig. 4. These characteristics are obtained by measuring the array voltampere for a different illumination values. From these characteristics, the optimum voltage or current, corresponding to the maximum power point, can be determined. It is clearly seen in Fig. 4 that the current increases as the irradiance levels increase. The maximum power point increases with a steep positive slope proportional to the illumination.

The main parameters which influence the illumination levels on a surface at a fixed tilt on earth are the daily and seasonal solar path, the presence of clouds, mist, smog and dust between the surface and the sunlight, and the shade of the object positioned such that the illumination level is reduced, etc.

The equation of the PV output current $I$ is expressed as a function of the array voltage $V$ :

$$
I=I_{\mathrm{sc}}-I_{\mathrm{o}}\left\{e^{\frac{q\left(V+I R_{s}\right)}{K T_{k}}}-1\right\}-\left(V+I R_{\mathrm{s}}\right) / R_{\mathrm{sh}}
$$

where $V$ and $I$ represent the PV output voltage and current, respectively; $R_{s}$ and $R_{s h}$ are the series and shunt resistance of the cell (in Fig. 3); $q$ is the electronic charge; $I_{s c}$ is the light-generated current; $\mathrm{I}_{\mathrm{o}}$ is the reverse saturation current; $K$ is the Boltzman constant, and $T_{k}$ is the temperature in $K$.

Equation (1) can be written in another form as [7] : 
$I=I_{s c}\left\{1-K_{1}\left[e^{K_{2} V^{m}}-1\right]\right\}-\left(V+I R_{\mathrm{s}}\right) / R_{\mathrm{sh}}$

where the coefficient $K_{1}, K_{2}$ and $\mathrm{m}$ are defined as

$K_{1}=0.01175$,

$K_{2}=K_{4} /\left(V_{o c}\right)^{m}$,

$K_{4}=\ln \left(\left(K_{1}+1\right) / K_{1}\right)$,

$K_{3}=\ln \left[\left(I_{s c}\left(1+K_{1}\right)-I_{m p p}\right) / K_{1} I_{s c}\right]$,

$m=\ln \left(K_{3} / K_{4}\right) / \ln \left(V_{m p p} / V_{o c}\right)$

$I_{m p p}$ is the current at maximum output power, $V_{m p p}$ is the voltage at maximum power, $I_{s c}$ is the short circuit current and $V_{o c}$ is the open circuit voltage of the array.

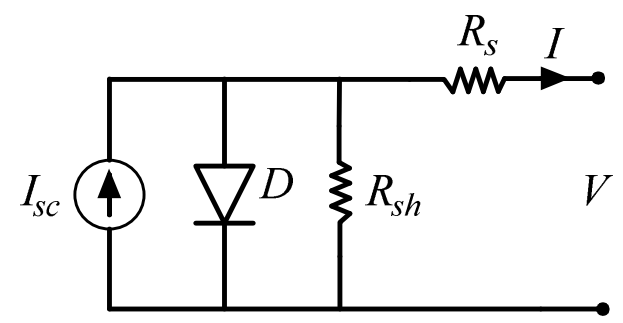

Fig. 3: Equivalent circuit of PV array.

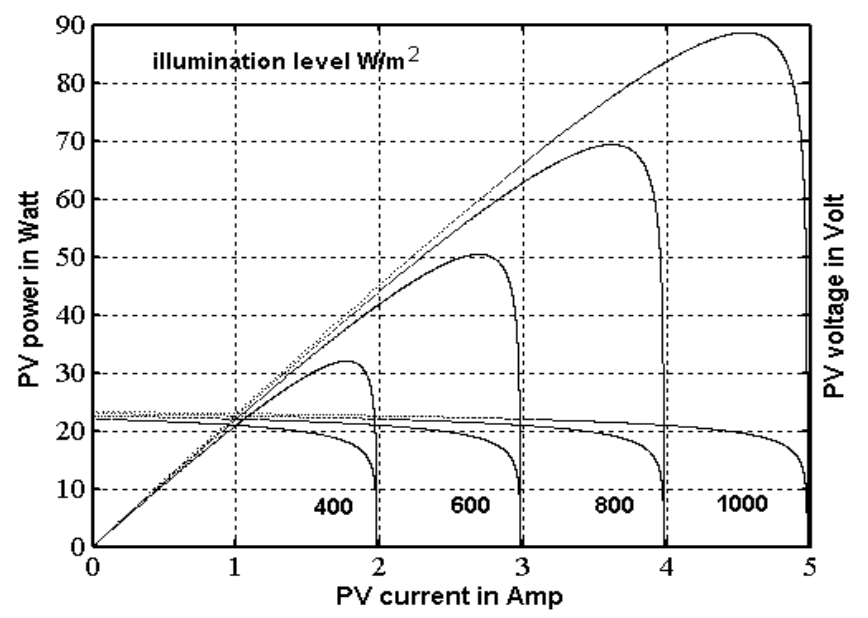

Fig. 4: V-I and P-I characteristics at constant temperature.

Equation (2) is only applicable at one particular operating condition of illumination $G$ and cell temperature $T_{c}$. The parameter variations can be calculated by measuring the variation of the short-circuit current and the open-circuit voltage in these conditions using the parameters at the normal illumination and cell temperature. Equation (2) is used for the $I-V$ and $P-V$ characteristics for various illumination and fixed temperature $\left(25\left[{ }^{\circ} \mathrm{C}\right]\right)$ in Fig. 4. 


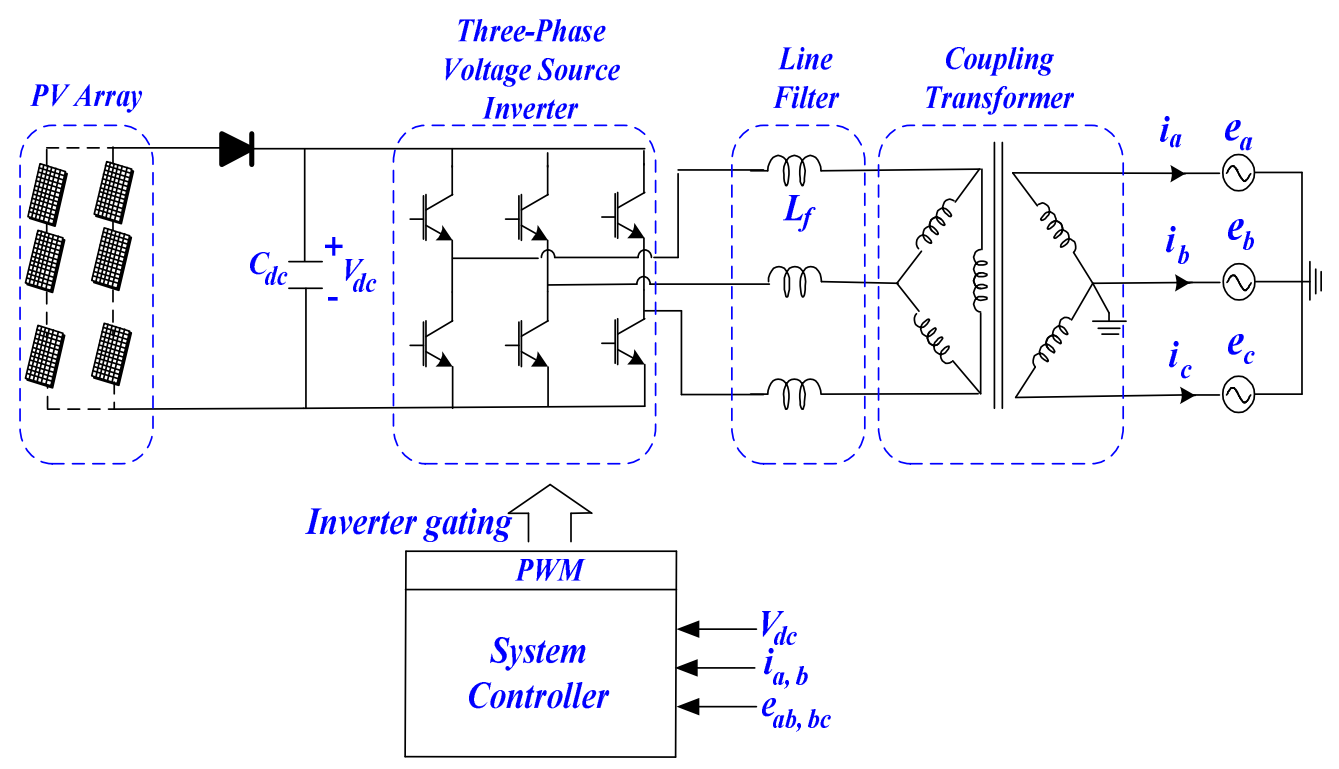

Fig. 5: Power circuit for PV system.

\section{SYSTEM DESCRIPTION}

Three-phase grid-connected voltage-source inverters (VSI) are employed to interface PV systems with electric power grids as shown in Fig. 5. The inverter circuit plays a role of an intermediate circuit for tracking the maximum power point and synchronizes the output current with the grid voltage, which means the power factor is equal to unity which flows into the utility or local. The connection to the utility grid is made by means of a step-up $\Delta-Y$ transformer, and second-order low pass filters are included in order to reduce the perturbation on the distribution system from highfrequency switching harmonics generated by the PWM control of the VSI.

To achieve these two goals, the three-phase line current is transformed from $\mathrm{ABC}$ reference frame to a dq rotating reference frame. The q-axis current is used to control the power flow from the PV to the grid. On the other hand, the d-axis current is used to control the output power factor to unity.

\section{SIMULATION RESULTS}

The full detailed model of the proposed three-phase grid-connected PV energy conversion system is implemented in the PSIM software environment as depicted in Fig. 6. Figure 7 shows the PV current variation according to the illumination variation from $1000[\mathrm{w} / \mathrm{m} 2]$ to $900[\mathrm{w} / \mathrm{m} 2]$ to $1000[\mathrm{w} / \mathrm{m} 2]$. The new incremental duty ratio varies according to the change in dc-ac inverter reference current. These relations between the input and output are determined in the base-rule form. It is noticed that the fast dynamic performance at step variation of illumination level is obtained. Figure 8 shows the unity power factor operation of the grid current and voltage. The output current is pure sinusoidal and the in phase with the grid voltage. The controller dynamics and unity power factor prove the validity of the controller performance. 


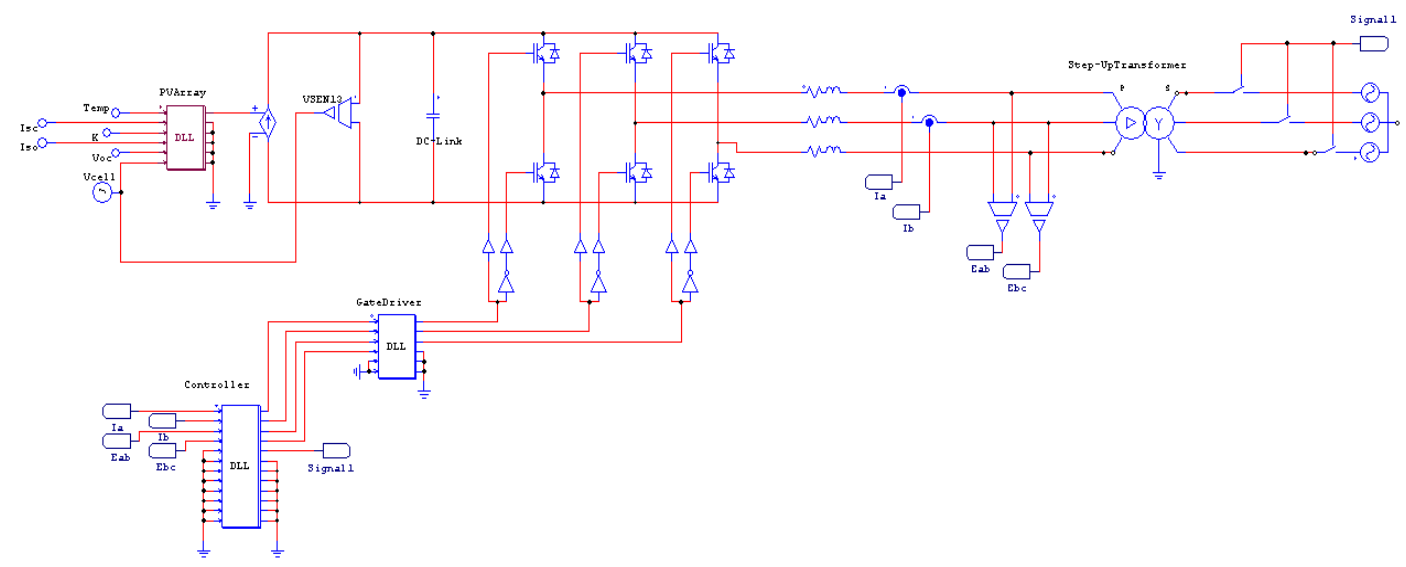

Fig. 6: Detailed model and control scheme of the grid-connected PV solar system in the PSIM environment.

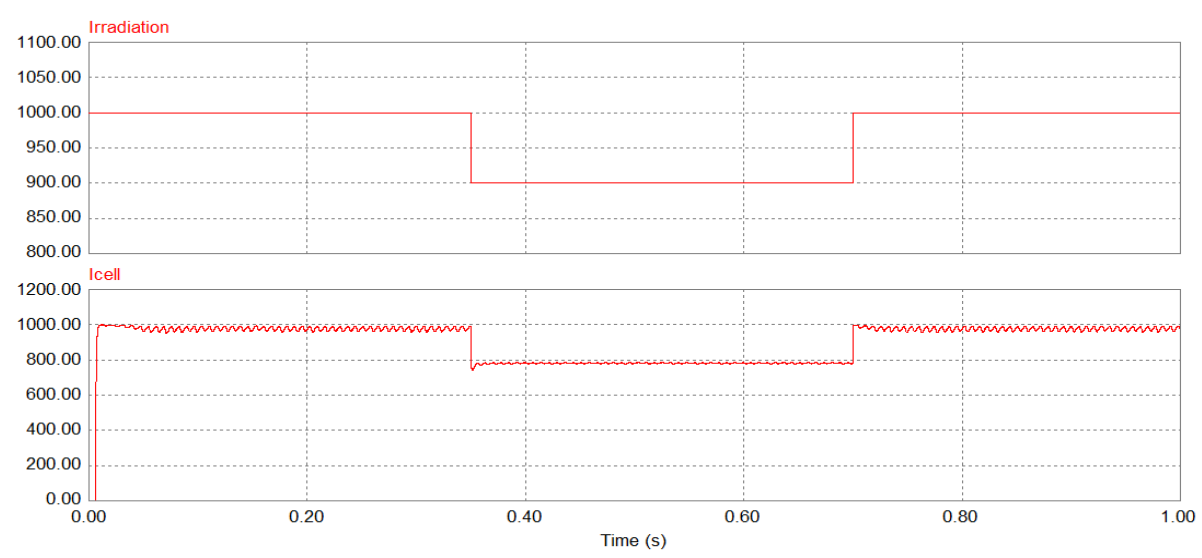

Fig. 7: PV current at different illumination levels

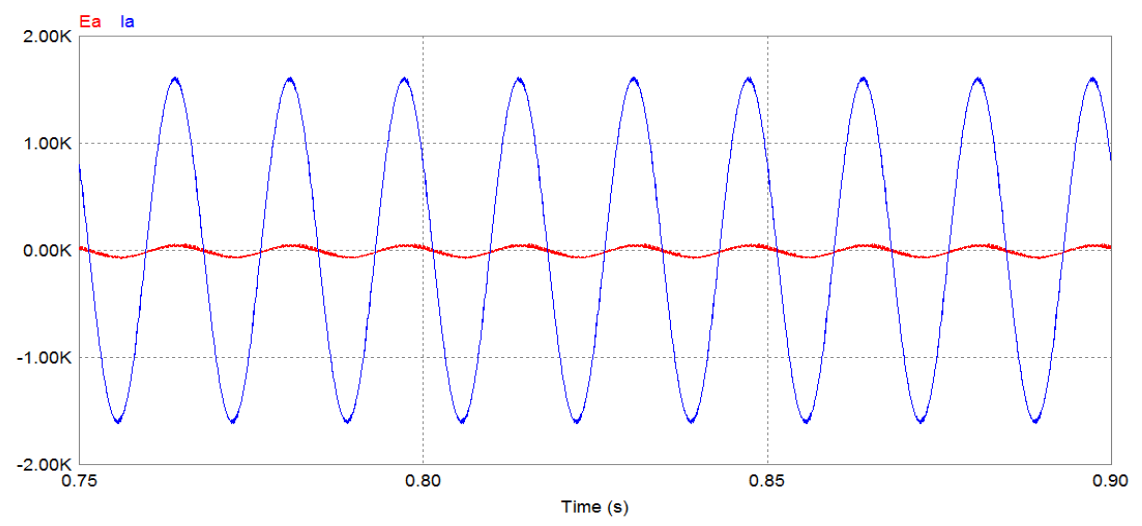

Fig. 8: Grid voltage and current Instantaneous waveforms 


\section{CONCLUSIONS}

This paper is focused on the modeling, design, and simulation of a grid connected large photovoltaic system controlled by the voltage oriented control for the Electrical Engineering Department Building in Assiut University. The paper suggests load profiles, sizing of a PV system for supplying the electrical load of the faculty using Hybrid Optimization Model for Electric Renewable (Homer) software.

\section{REFERENCES}

[1] W. Xiao, N. Ozog, and W. G. Dunford, "Topology study of photovoltaic interface for maximum power point tracking," IEEE Trans. Ind. Electron., vol. 54, no. 3, pp. 1696-1704, Jun. 2007.

[2] L. Chang and H.M. Kojabadi, "Review of interconnection standards for distributed power generation," Large Engineering Systems Conference on Power Engineering 2002 (LESCOPE' 02), pp.36 - 40, June 2002.

[3] N. Patcharaprakiti and S. Premrudeepreechacharn, "Maximum power point tracking using adaptive fuzzy logic control for grid-connected photovoltaic system", in IEEE Power Engineering Winter Meeting, 2002.

[4] Soeren B. Kjaer, John K. Pedersen and Frede Blaabjerg, "A Review of SinglePhase Grid-Connected Inverters for Photovoltaic Modules," IEEE Transactions on Industry Applications, Vol. 41, No. 5, Sep. 2005.

[5] A. A. Hassan1, A. A. Nafeh1, F. H. Fahmy, Mohamed A. El-Sayed, "Stand-Alone Photovoltaic System for an Emergency Health Clinic," Proc. International Conference on Renewable Energies and Power Quality (ICREPQ'10), March 2010.

[6] Egyptian solar radiation atlas, Cairo, Egypt, 1998.

[7] B. G. YU, A. G. Abo-Khalil, M. Matsui, G. J Yu, "Sensorless Fuzzy Logic Controller for Maximum Power point Tracking of Grid, "IEEE proc. of International Conference on Electrical Machines and Systems, vol. 1, Dec. 2009.

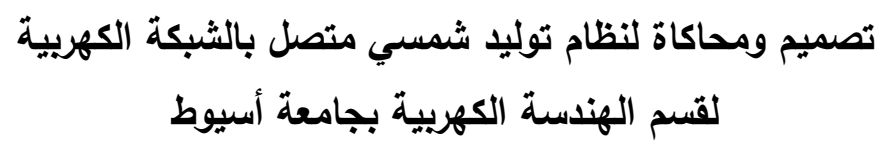

$$
\begin{aligned}
& \text { في هذا البحث تصمبم كامل لنظام شدسي متصل بشبكة الكهباء لتغذية قسم الهندسة الكهبية بجزء من } \\
& \text { القدة المطلوبة للأحمال وذلك بناءً على احتباجات القسم من الطاقة. وتم حساب حجم وتكلفة ومواصفات النظام } \\
& \text { الثدسي المطلوب من خلايا شمسية وموحدات ومكونات باستخدام برنامج هومر • كما تم محاكاة عمل هذه } \\
& \text { الخلايا ومحاكاة ربطها بالقسم والثبكة من خلال برنامج " البي سبم " والذي أمكن من خلاله مشاهدة القدة }
\end{aligned}
$$

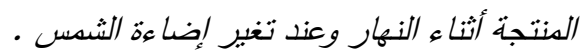

